\title{
Effects of Forest Management on Amphibians and Reptiles: Generalist Species Obscure Trends Among Native Forest Associates
}

\author{
David A. Steen ${ }^{*}$, Ashley E. Rall McGee, Sharon M. Hermann, James A. Stiles, Sierra H. Stiles and \\ Craig Guyer
}

Department of Biological Sciences, Auburn University, Auburn, Alabama 36849 USA

\begin{abstract}
In the future, land stewards are expected to increase their use of fire surrogates to manage longleaf pine forests. Varying land management strategies may have disparate effects on wildlife and the strength of these effects may depend upon the degree to which each target species is associated with the longleaf pine forest. To determine how amphibian and reptile assemblages respond to prescribed burns and fire surrogates, we sampled these animals within plots of land managed under four common management practices (burning, thinning, thinning and burning, and application of herbicide) and on unmanaged reference plots. We analyzed these data first by examining the entire herpetofauna and then by repeating all analyses for only taxa exhibiting some evidence of an evolutionary association with longleaf pine forests. We found that estimates of species richness of all amphibians did not differ significantly among treatments. These trends were altered when the pool of taxa was restricted to amphibian species known to be associated with longleaf pine forests. For associated amphibians, species richness was elevated on plots that were exposed to herbicide and burn, hardwood thinning, and hardwood thinning plus prescribed fire, relative to reference plots. No significant trends were identified for squamates in general or those squamate species known to be associated with longleaf forests. Fire surrogates may facilitate conservation for individual species of the ancestral biota of longleaf pine forests, but these trends may be obscured when entire assemblages are considered.
\end{abstract}

Keywords: Prescribed burn, fire surrogate, hardwood removal, herbicide treatment, longleaf pine, Pinus palustris, thinning.

\section{INTRODUCTION}

Longleaf pine, Pinus palustris, forests once dominated the uplands of the Southeastern United States [1]. Years of conversion to residential development, agriculture and industrial forestry, among other land uses, have reduced this ecosystem to a small fraction of its historic extent [2]. As conservation and maintenance of remaining longleaf pine forests have increased in priority, so has interest in effective forest management.

Longleaf pine forests are described as pyrogenic [3] and prescribed fire is thought to be the single most important factor in restoration and management of longleaf pine forests [4]. Frequent fire suppresses hardwood invasion and reduces undergrowth. Burning maintains an herbaceous understory and, over long periods of time, yields an open aspect favorable to species adapted to longleaf forests [5].

Fire is thought to be a vital ecological process for longleaf pine forests and a return interval of once every 2 to 4 years is thought to have characterized these forests prior to settlement of this region by humans of European origin [6]. Consequently, wildlife species associated with the longleaf pine system are well-adapted to fire's effects [7]. For example, gopher tortoises, Gopherus polyphemus, prefer fire-maintained habitats [8]; in turn, tortoise burrows provide

*Address correspondence to this author at the Department of Biological Sciences, Auburn University, Auburn, Alabama 36849 USA;

Tel: 334-844-8770; Fax: 334-844-9234;

E-mail: davidasteen@gmail.com refuge for animals from approaching fire [9], making tortoise burrows a key conservation resource.

Despite clear benefits of fire to both longleaf pine forests and associated wildlife, prescribed burns are not always a feasible management option due to small parcel sizes, containment risk, and smoke hazards [10]. Accordingly, managers have identified alternative techniques that may serve as surrogates for prescribed burning, including mechanical removal of hardwoods and application of herbicides. Although effects of these strategies on vegetation structure may mirror those resulting from natural processes, understanding wildlife responses requires study and is expected to vary among taxonomic groups [11].

The current study was part of a larger national-level project to assess effects of different fire surrogate treatments over 12 sites that spanned the entire country. Boerner et al. [12] provided an overview of the national study and Schwilk et al. [13] summarized general results of treatments on fuels and vegetation structure. The project assessed treatments that have potential to reduce hazardous wildland fuels in natural ecosystems and compared results with those created by prescribed fire $[12,14]$.

Past research on amphibians and reptiles indicates that response of these organisms to fire is highly dependent on the natural history and habitat preferences of each species [15-19] and may be influenced by the frequency, timing (both month of fire and time since last burn), or intensity of a burn. Interestingly, Schurbon and Fauth $[18,20]$ documented negative effects of prescribed burning on the overall amphibian assemblage of longleaf pine forests and 
advocated burning on intervals longer than typically recommended for this forest type (e.g. [21, 22]). However, hardwood vegetation can encroach quickly into longleaf pine forests from which fire has been excluded [23], altering the habitat from one that favors taxa adapted to open pine stands to one that favors taxa adapted to hardwood forests. In such a setting, species richness might increase on areas with a long fire-return interval because hardwood-adapted species increase faster than pine-adapted species decrease [24] resulting in a mixture of both types of species, until a new equilibrium is reached. Because taxa that have geographic ranges that are restricted to areas occupied by longleaf pine are unusually common on lists of species of conservation concern [25], such taxa are the logical focus for assessing effects of methods proposed for restoration of longleaf pine forests [26].

In this study, we used a replicated design to assess how prescribed burning, thinning, herbicide use with burning, and a combination of thinning and burning influenced amphibian and reptile assemblages in an Alabama longleaf pine forest. As in previous studies [cf. 18], we used species richness to assess effects of these treatments relative to reference sites receiving no management efforts. However, we also compared overall patterns of species richness with patterns based on taxa that are associates of longleaf pine (defined below) to test the effect that refining a reference assemblage might have on interpretation of restoration methods proposed for longleaf forests.

\section{MATERIALS AND METHODOLOGY}

\section{Study Area and Treatments}

This research was conducted at the Solon Dixon Forestry Education Center, a 2145 ha property surrounded by the Conecuh National Forest in south-central Alabama. The site is owned and managed by the School of Forestry and Wildlife Science at Auburn University for educational purposes. Overall, the area is managed for recreation, timber production, and research.

Fifteen, 12.25 ha study sites, each with a $20 \mathrm{~m}$ buffer, were established within forested longleaf pine uplands in 2002. All were selected because they had similar recent management histories and forest structures that were as closely matched as possible. One of five different treatments was randomly administered to each site (three replicates per treatment), and sites were grouped into three blocks [27], each including a site that received 1) a prescribed burn (PB), 2) a herbicide application to hardwoods followed by prescribed burn (HPB) 3) a thinning of hardwoods (T), 4) a thinning of hardwoods followed by prescribed burn (TPB), or 5) no management (reference sites; R).

For treatments including thinning ( $\mathrm{T}$ and $\mathrm{TPB}$ ), hardwoods were targeted for removal so that a residual basal area equaled ca. $5.6 \mathrm{~m}^{2}$ per 0.4 ha [27]. To create comparable canopy cover, on some sites there was also removal of some loblolly pine, Pinus taeda (a species not normally found in longleaf forests). These sites were thinned in late March or early April of 2002 and fire was applied to PB and TPB sites from April-May of 2002 and 2004. Herbicide (4.0-4.5\% solution of Garlon4) was applied to HPB sites in September of 2002 and prescribed fire was applied to them in April or May of 2003.

\section{Trapping}

In 2002, a drift fence array was established within each site. Each array included three walls of aluminum flashing sheets $(15 \mathrm{~m}$ long and $61 \mathrm{~cm}$ tall) that were embedded into 3 $\mathrm{cm}$ deep trenches. The walls radiated from a centrally located 18.9 L bucket that served as a pitfall trap. Buckets were also located at the distal end of each wall [modified from 28].

Commencing in March of 2003, we used snake traps as described in Rudolph et al. [29] to sample large squamates that could escape our other traps. One snake trap was positioned on each site. Traps were cuboid in shape, $0.3 \mathrm{~m}$ tall, $1.0 \mathrm{~m}$ along each side, and contained a funnel-shaped entrance to the center of each side. A $9.1 \mathrm{~m}$ length of hardware cloth $(61 \mathrm{~cm}$ tall) originated at each funnel and extended outward from the trap. The hardware cloth was embedded into a $3 \mathrm{~cm}$ deep trench creating four drift fences. Traps remained open and were checked approximately daily from April 2002 through August of 2002, and from April 2003 through March 2005. After capture, animals were measured, marked, and released within $4.0 \mathrm{~m}$ of the trap.

\section{Characterization of Longleaf Pine Associates}

We designated a species as a longleaf pine associate based on a previous review of geographic ranges of amphibians and reptiles in relation to the geographic range of longleaf pine. In that work, Guyer and Bailey [25] identified species whose geographic ranges extended beyond that of longleaf pine forest, but that were known to maintain viable populations within longleaf. They identified these animals as longleaf pine residents. Those species with at least $80 \%$ of their geographic ranges located within that of longleaf pine were deemed longleaf pine specialists. Because we captured relatively few specialist species, we grouped them with residents into a category we now call longleaf pine associates.

\section{Statistical Analyses}

We estimated species richness using Chaol estimators [30] as implemented in EstimateS [31]. Because unadjusted counts of observed species do not account for the potential of incomplete sampling, our species richness estimator considered the rate at which new species were added to the species pool over time to determine how many species were likely present but may not have been recorded during a sampling effort [32]. To maximize this benefit, we pooled replicate sites within treatments for each month of the study, eliminating the block effect from our design. Thus, our estimates of species richness were generated for species $\mathrm{x}$ month matrices for each of the five treatments [13, 27].

We created independent matrices for amphibians and squamates, resulting in a total of ten matrices. We created additional matrices for each treatment by removing species not considered longleaf pine associates, as defined by Guyer and Bailey [25]. We did not include turtles in our analyses because sample sizes were low and our trapping effort was not designed to capture these animals. As a conservative 
Table 1. Total Amphibians and Reptiles Captured within Prescribed Burn and Prescribed Burn Surrogate Treatments in an Alabama Longleaf Pine Forest, 2002-2005

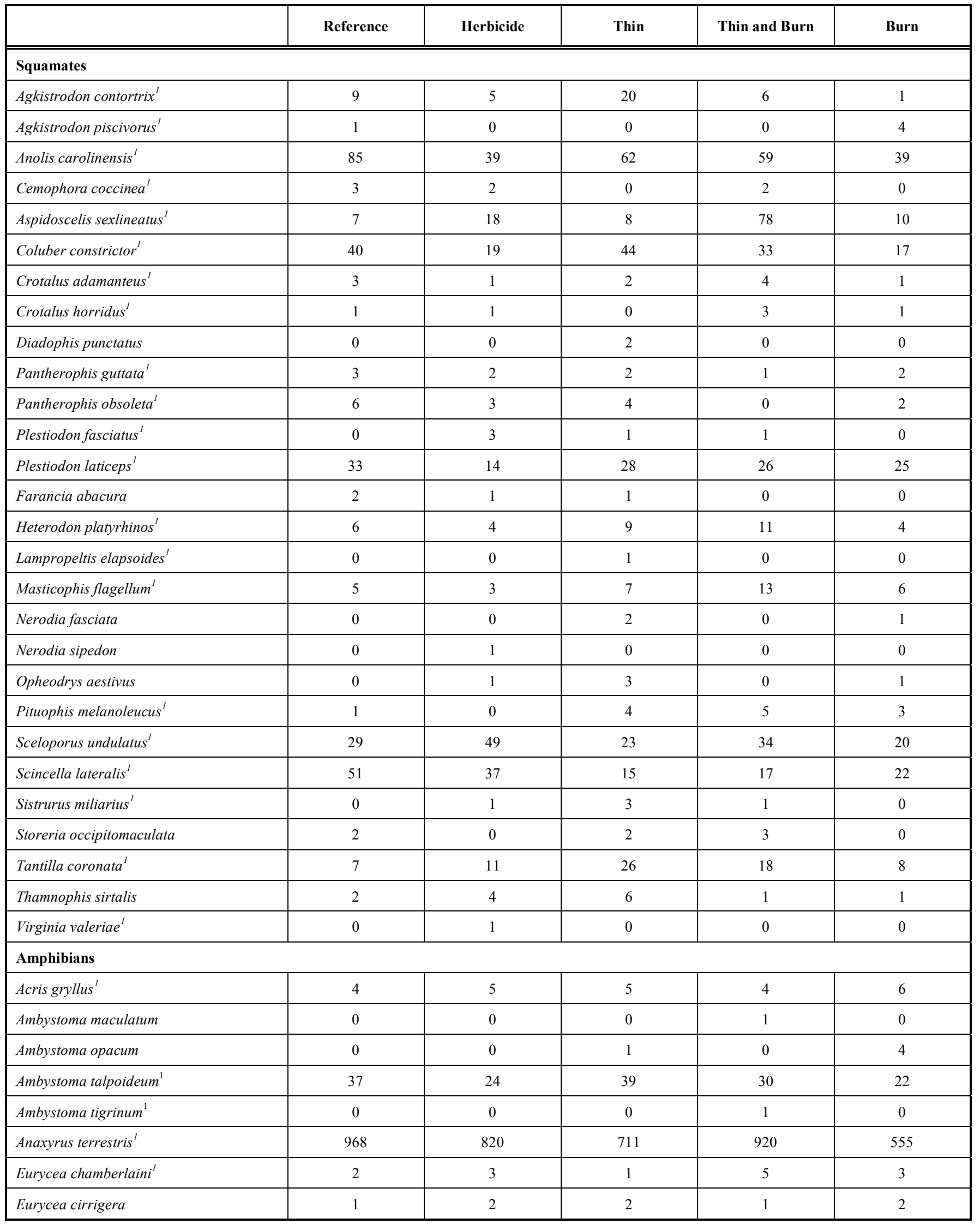




\begin{tabular}{|c|c|c|c|c|c|}
\hline & Reference & Herbicide & Thin & Thin and Burn & Burn \\
\hline \multicolumn{6}{|l|}{ Amphibians } \\
\hline Hyla chrysoscelis ${ }^{l}$ & 4 & 2 & 4 & 7 & 0 \\
\hline Hyla cinerea ${ }^{l}$ & 1 & 0 & 1 & 3 & 0 \\
\hline Hyla gratiosa ${ }^{l}$ & 5 & 6 & 2 & 13 & 8 \\
\hline Hyla squirella ${ }^{l}$ & 2 & 0 & 2 & 1 & 1 \\
\hline Notophthalmus viridescens ${ }^{l}$ & 6 & 21 & 17 & 6 & 9 \\
\hline Pseudacris ornata ${ }^{l}$ & 0 & 4 & 0 & 0 & 1 \\
\hline Pseudotriton ruber & 0 & 3 & 1 & 2 & 0 \\
\hline Lithobates catesbieana & 3 & 3 & 42 & 1 & 5 \\
\hline Lithobates clamitans & 172 & 41 & 205 & 77 & 23 \\
\hline Lithobates sphenocephalus ${ }^{l}$ & 86 & 41 & 58 & 77 & 25 \\
\hline Scaphiopus holbrooki ${ }^{l}$ & 187 & 508 & 92 & 216 & 577 \\
\hline
\end{tabular}

Longleaf pine associate, derived from Guyer and Bailey [25].

evaluation of treatment effects, we considered $95 \%$ confidence intervals of species richness that did not overlap to be significantly different, following Payton et al. [33].

\section{RESULTS}

Twenty-eight species of squamates and 24 species of amphibians were captured and included in our analyses
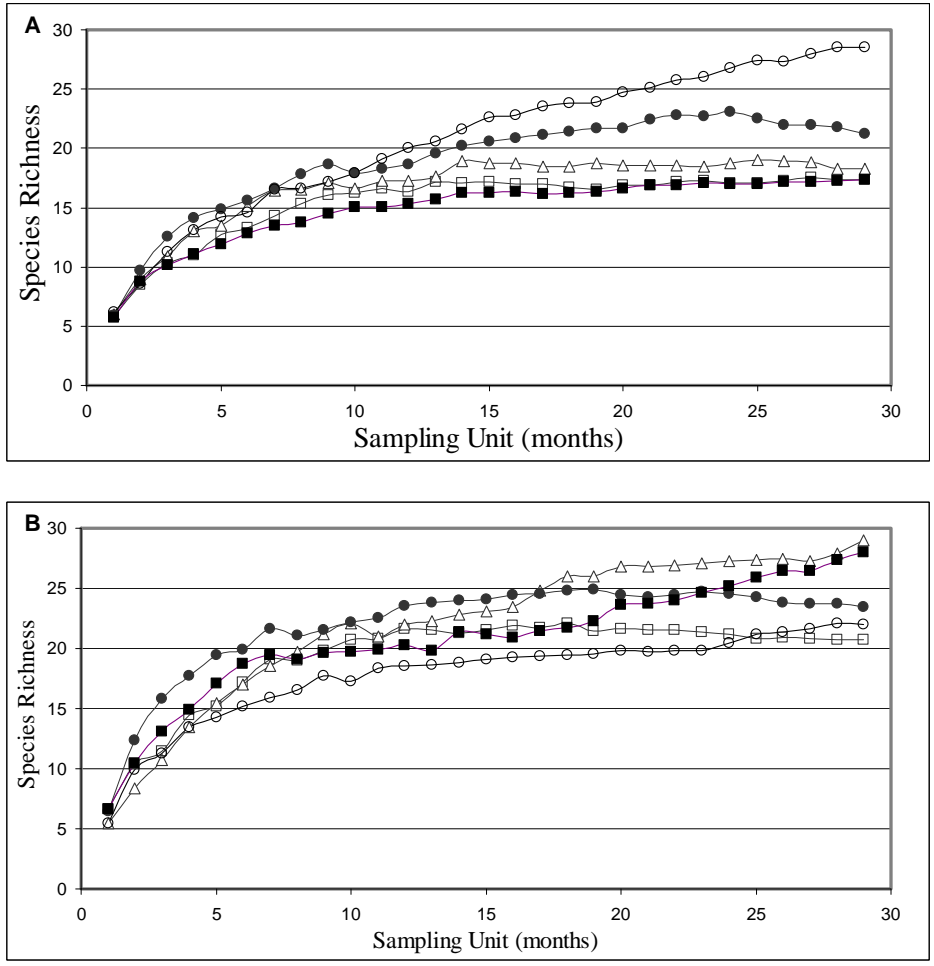

Fig. (1). Species accumulation curves for all amphibian (A) and squamate (B) species captured within prescribed burn, prescribed burn surrogate treatments, and reference plots within an Alabama longleaf pine forest, 2002-2005. Open square $=$ reference; closed square $=$ prescribed burn; open circle $=$ thin and burn; closed circle $=$ thin; open triangle $=$ herbicide and burn . 
(Table 1). Total numbers of captures varied among species from 1 (e.g. Lampropeltis elapsoides) to 3974 (Anaxyrus terrestris) and among treatments from 2054 (T) to 2669 (HPB).

Species accumulation curves for all species generally reached asymptotes in all treatments, indicating sampling effort was sufficient to detect the local herpetofauna (Fig. 1) although curves for amphibians in TPB treatments indicate gradual increases. When all amphibians and squamates were included in analyses, 95\% confidence intervals overlapped among all treatments. When we restricted our analysis to species considered longleaf pine associates, confidence intervals surrounding species richness estimates for amphibians on R sites were exceptionally low. Species richness was estimated to be significantly greater for TPB, HPB, and T treatments relative to R sites (Table 2, Fig. 2).

Table 2. Species Richness Estimates (Chao1) for Amphibians and Squamates Captured within Prescribed Burn, Prescribed Burn Surrogate Treatments, and Reference Plots within an Alabama Longleaf Pine Forest, 2002-2005

\begin{tabular}{|c|c|c|c|}
\hline & Species Richness & $95 \% \mathrm{CI}$ & $95 \% \mathrm{CI}$ \\
\hline \multicolumn{4}{|l|}{ All Amphibians } \\
\hline Reference & 17.33 & 17.02 & 22.96 \\
\hline Herbicide & 18.25 & 18.01 & 22.79 \\
\hline Thin & 21.2 & 20.14 & 30.37 \\
\hline Thin and Burn & 28.5 & 22.32 & 63.53 \\
\hline Burn & 17.33 & 17.02 & 22.96 \\
\hline \multicolumn{4}{|c|}{ Associate Amphibians } \\
\hline Reference & 14 & 14 & 14 \\
\hline Herbicide & 14.33 & 14.02 & 19.96 \\
\hline Thin & 15.25 & 15.01 & 19.79 \\
\hline Thin and Burn & 19 & 16.35 & 41.53 \\
\hline Burn & 13.5 & 13.03 & 21.26 \\
\hline \multicolumn{4}{|l|}{ All Reptiles } \\
\hline Reference & 20.75 & 20.07 & 28.45 \\
\hline Herbicide & 29 & 23.34 & 58.54 \\
\hline Thin & 23.5 & 23.04 & 29.21 \\
\hline Thin and Burn & 22 & 19.39 & 42 \\
\hline Burn & 28 & 20.52 & 72.28 \\
\hline \multicolumn{4}{|c|}{ Associate Reptiles } \\
\hline Reference & 20 & 17.35 & 42.57 \\
\hline Herbicide & 20 & 18.25 & 34.01 \\
\hline Thin & 18 & 17.09 & 27.68 \\
\hline Thin and Burn & 18.5 & 17.15 & 32.08 \\
\hline Burn & 17 & 16.09 & 26.68 \\
\hline
\end{tabular}

\section{DISCUSSION AND CONCLUSION}

Our data document that interpretations of fire effects can be dependent upon the definition of the target taxa. When all recorded amphibian species were included in our analyses, species richness estimates did not differ among managed sites and reference sites, although estimated richness was at least 7 species greater on TPB sites than any other treatment. Our failure to document that such a trend was statistically significant resulted from the fact that variances around richness estimates were comparable for all treatments except for TPB, which had a notably greater variance. For amphibian associates of longleaf pine forests, however, estimates of species richness were significantly lower on $\mathrm{R}$ sites than all other treatments except B sites because the variance around estimates for $\mathrm{R}$ sites was remarkably small.

The reduction in variance may result from the presence of a consistent set of longleaf pine associate amphibians that are capable of surviving in shrub-dominated habitats of firesuppressed landscapes. Species that are tolerant of such conditions are absent from state lists of species of conservation concern because these taxa are capable of withstanding the conditions created in human-altered landscapes in which frequent fire has been removed. Although HPB and T sites had statistically greater species richness than $\mathrm{R}$ sites, these differences are unlikely to be biologically meaningful because they represent at most one additional species relative to $\mathrm{R}$ sites. However, the increase of five species observed on TPB sites is considerable. TPB is the only treatment on which Tiger Salamanders (Ambystoma tigrinum) were observed, a species of conservation concern throughout the longleaf pine ecosystem [25]. We suggest that sensitive species, like Pseudacris ornata and Pseudacris nigrita, that were observed only on some treatment plots, and other sensitive species, like Eurycea quadridigitata and Ambystoma bishopi, that occurred on no study plot but are known from the area, comprise the additional species expected to be present, but not detected, on TPB treatments because of their affinity for open upland habitats.

Thus, we argue that the TPB treatment alters the landscape to re-create aspects of the ancestral landscape and this is likely to retain sensitive amphibian associates of longleaf pine forests. Such a finding is masked if all species are included, a feature suggested by Means et al. [24] in evaluating the work of Schurbon and Fauth [18]. Our results suggest that over the course of a few years, burning or thinning alone is unlikely to create the features that both techniques implemented simultaneously are likely to cause. This may be attributed to attainment of the ancestral habitat conditions more quickly when both techniques are used in concert. Longer-term studies are necessary to determine if the ancestral condition can be eventually achieved by either of the strategies employed alone.

Similar patterns of diversity were not observed in squamates. For these taxa species richnesses and variances were comparable when evaluated for all taxa and for species associated with longleaf pine forests. The lack of an effect on richness is surprising given that squamate associates, like Aspidoscelis sexlineatus [34] and Plestiodon inexpectatus 

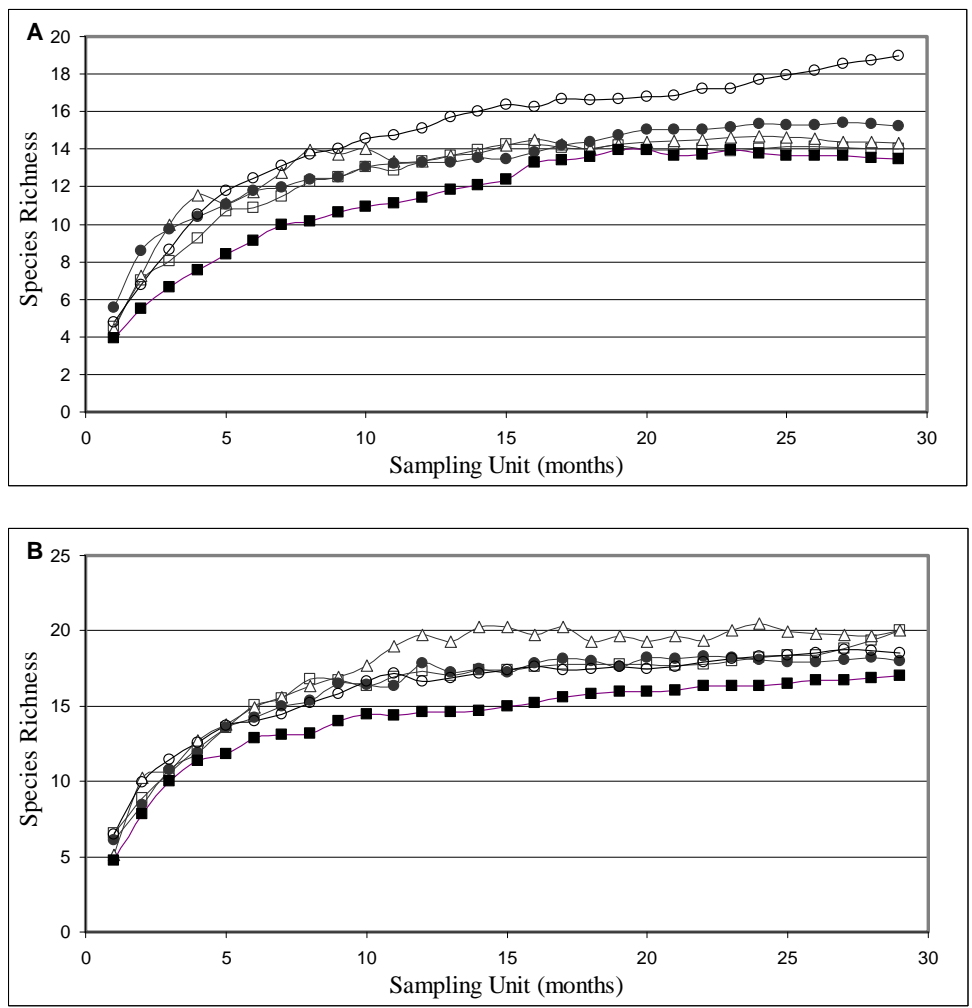

Fig. (2). Species accumulation curves for amphibian (A) and squamate (B) species considered longleaf pine associates captured within prescribed burn, prescribed burn surrogate treatments, and reference plots within an Alabama longleaf pine forest, 2002-2005. Open square $=$ reference; closed square $=$ prescribed burn; open circle $=$ thin and burn; closed circle $=$ thin; open triangle $=$ herbicide and burn .

[9], are known to respond to fire at spatial scales comparable to ours. Although we did observe an increase in the number of individuals of $A$. sexlineatus and a decrease in abundance of Scincella lateralis (a hardwood-adapted species) trapped on TPB sites (Table 1), no treatment effect on patterns of diversity was documented for our samples of squamates. We attribute this to the large-scale movement capabilities and the longer generation times of this group, relative to the scale of management and temporal monitoring associated with this study (e.g. [15]).

Although land in the southeast is often managed specifically for individual species, such as bobwhite quail, Colinus virginianus, or red-cockaded woodpecker, Picoides borealis, amphibians and reptiles rarely provide a focus for such activities. Because these two groups have disparate natural history characteristics, their response to management efforts likely will differ $[35,36]$. In the specific case of management techniques that limit hardwood encroachment into uplands of longleaf pine forests, increased species richness is expected of amphibian species known to be associated with this forest type, but a similar result for reptiles has yet to be documented. Longer term studies may be necessary to incorporate the ongoing habitat changes associated with a management strategy and its effects on associated reptiles [37].

\section{ACKNOWLEDGEMENTS}

This is contribution number 203 of the National Fire and Fire Surrogate Project (FFS), funded by the U.S. Joint Fire Science Program. We thank the staff of the Solon Dixon
Forestry Education Center for application of the treatments and Auburn University for access to the sites. K. Barrett provided insightful comments on an earlier version of this manuscript.

\section{REFERENCES}

[1] Frost CC. Four centuries of changing landscape patterns in the longleaf pine ecosystem. Proceedings of the Tall Timbers Fire Ecology Conference, No. 18, The Longleaf Pine Ecosystem; Ecology, Restoration and Management Florida, USA 1993.

[2] Noss RF. Longleaf pine and wiregrass: keystone components of an endangered ecosystem. Nat Areas J 1989; 9: 211-3.

[3] Platt WJ, Evans GW, Rathbun SL. The population dynamics of a long-lived conifer (Pinus palustris). Am Nat 1988; 131: 491-525.

[4] Mitchell RJ, Hiers JK, O'Brien JJ, Jack SB, Engstrom RT. Silviculture that sustains: the nexus between silviculture, frequent prescribed fire, and conservation of biodiversity in longleaf pine forests of the southeastern United States. Can J Forest Res 2006; 36: 2724-36.

[5] Jose S, Jokela EJ, Miller DL, Eds. The longleaf pine ecosystem ecology, silviculture, and restoration. Springer Science: New York, USA 2006.

[6] Brockway DG, Lewis CE. Long-term effects of dormant-season prescribed fire on plant community diversity, structure, and productivity in a longleaf pine wiregrass ecosystem. For Ecol Manage 1997; 96: 167-83.

[7] Wood GW, Ed. Prescribed fire and wildlife in southern forests. Belle Baruch Forest Science Institute. DNR News, Clemson University, South Carolina: USA 1981.

[8] Diemer JE. The ecology and management of the gopher tortoise in the southeastern United States. Herpetologica 1986; 42: 125-33.

[9] Mushinsky HR. Natural history and abundance of southeastern five-lined skinks, Eumeces inexpectatus, on a periodically burned sandhill in Florida. Herpetologica 1992; 48: 307-12. 
[10] Smith DM, Larson BC, Kelty MJ, Ashton PMS. The practice of silviculture: applied forest ecology. John Wiley \& Sons, Inc: New York, USA 1997.

[11] Russell KR, Van Lear DH, Guynn DC Jr. Prescribed fire effects on herpetofauna: a review and management implications. Wildl Soci Bull 1999; 27: 374-84

[12] Boerner REJ, Hart SC, McIver JD. The national fire and fire surrogate study: Ecological consequences of alternative fuel reduction methods in seasonally dry forests. For Ecol Manage 2008; 255: 3075-80

[13] Schwilk DW, Keeley JE, Knapp EE, et al. The national Fire and Fire Surrogate study: effects of fuel reduction methods on forest vegetation structure and fuels. Ecol Appl 2009; 19: 285-304.

[14] McIver J, Youngblood A, Stephens SL. The national Fire and Fire Surrogate study: ecological consequences of fuel reduction methods in seasonally dry forests. Ecol Appl 2009; 19: 283-4.

[15] Greenberg CH, Neary DG, Harris LD. Effect of high-intensity wildfire and silvicultural treatments on reptile communities in sand-pine scrub. Conserv Biol 1994; 8:1047-57.

[16] McLeod RF, Gates JE. Response of herpetofaunal communities to forest cutting and burning at Chesapeake Farms, Maryland. Am Midl Nat 1998; 139: 164-77.

[17] Litt AR, Provencher L, Tanner GW, Franz R. Herpetofaunal responses to restoration treatments of longleaf pine. Restoration Ecol 2001; 9: 462-74.

[18] Schurbon JM, Fauth JE. Effects of prescribed burning on amphibian diversity in a southeastern U.S. National Forest. Conserv Biol 2003; 17: 1338-49.

[19] Wilgers DJ, Horne EA. Effects of different burn regimes on tallgrass prairie herpetofaunal species diversity and community composition in the Flint Hills, Kansas. J Herpetol 2006; 40:73-84.

[20] Schurbon JM, Fauth JE. Fire as friend and foe of amphibians: a reply. Conserv Biol 2004; 18:1156-9.

[21] Hermann SM. Stoddard fire plots: lessons for land management thirty-five years later. Proceedings of the Tall Timbers Game Bird Seminar; Tallahassee, Florida 1995

[22] Robertson KM, Ostertag TE. Problems with Schurbon and Fauth's test of effects of prescribed burning on amphibian diversity. Conserv Biol 2004; 18:1154-5.

[23] Aresco MJ, Guyer C. Burrow abandonment by gopher tortoises in slash pine plantations of the Conecuh National Forest. J Wildl Manage 1999; 63:26-35

[24] Means DB, Dodd CK Jr., Johnson SA, Palis JG. Amphibians and fire in longleaf pine ecosystems: Response to Schurbon and Fauth. Conserv Biol 2004; 18: 1149-53.
[25] Guyer C, Bailey MA. Amphibians and reptiles of longleaf pine communities. Proceedings of the Tall Timbers Fire Ecology Conference, No. 18, The Longleaf Pine Ecosystem; Ecology, Restoration and Management; Florida, USA 1993.

[26] Block WM, Franklin AB, Ward JP Jr, Ganey JL, White GC. Design and implementation of monitoring studies to evaluate the success of ecological restoration on wildlife. Restoration Ecol 2001; 9: 293303.

[27] Rall AE. Effects of longleaf pine management practices on the herpetofauna of south Alabama. Auburn University, USA 2004

[28] Scott NJ Jr. Herpetological Communities. U. S. Fish and Wildlife Service Report 13, Washington DC: USA 1982

[29] Rudolph DC, Burgdorf SJ, Conner RN, Schaefer RR. Preliminary evaluation of the impact of roads and associated vehicular traffic on snake populations in eastern Texas. Proceedings of the third international conference on wildlife ecology and transportation; Florida, Florida, USA 1999.

[30] Chao A. Nonparametric estimation of the number of classes in a population. Scand J Stat 1984; 11: 265-70.

[31] Colwell RK. EstimateS: statistical estimation of species richness and shared species from samples. Version 8. Persistent URL $<$ purl.oclc.org/estimates $>2006$.

[32] Gotelli NJ, Colwell RK. Quantifying biodiversity: procedures and pitfalls in the measurement and comparison of species richness. Ecol Lett 2001; 4:379-1.

[33] Payton ME, Greenstone MH, Schenker N. Overlapping confidence intervals or standard error intervals: what do they mean in terms of statistical significance? J Insect Sci 2003; 3:34

[34] Mushinsky HR. Fire and the Florida sandhill herpetofaunal community: with special attention to responses of Cnemidophorus sexlineatus. Herpetologica 1985; 41: 333-42.

[35] Bailey MA, Holmes JN, Buhlmann KA, Mitchell JC. Habitat management guidelines for amphibians and reptiles of the southeastern United States. Partners in Amphibian and Reptile Conservation Technical Publication HMG-2, Montgomery, Alabama 2006; p. 88.

[36] Barrett, K, Guyer C. Differential responses of amphibians and reptiles in riparian and stream habitats to land use disturbances in western Georgia, USA. Biol Conserv 2008; 141: 2290-300.

[37] Greenberg CH, Waldrop TA. Short-term response of reptiles and amphibians to prescribed fire and mechanical fuel reduction in southern Appalachian upland hardwood forest. For Ecol Manage 2008; 255: 2883-93.

This is an open access article licensed under the terms of the Creative Commons Attribution Non-Commercial License (http://creativecommons.org/licenses/by$\mathrm{nc} / 3.0 /$ ) which permits unrestricted, non-commercial use, distribution and reproduction in any medium, provided the work is properly cited. 